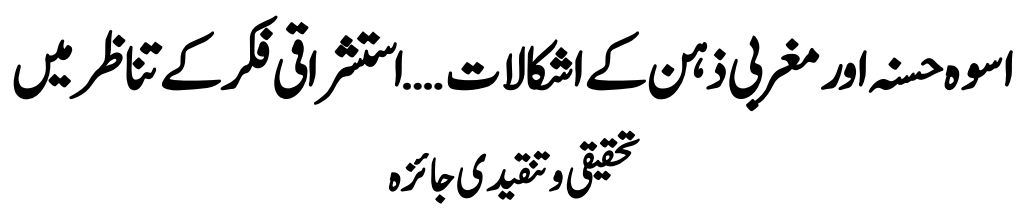

\title{
Western Understanding of the Sirah of the Holy Prophet (PBUH) with Orientalistic Approach.... ACritical Analysis
}

Fozia Fiaz

HoD, Assistant Professor, Islamic Studies University of Sialkot.

Ammara Tabassum

Assitant Professor I.R. Department, University of Sialkot.

Naeem Qaiser Alazhari

Lecturer Islamic Studies, University of Sialkot.

KEYWORDS

Sirah

West

Intellectual Evolution

Perplexity

\begin{tabular}{ll} 
DATES & \\
\hline Received & $06-10-2021$ \\
Accepted & $03-12-2021$ \\
Published & $21-12-2021$ \\
QR CODE & \\
\hline
\end{tabular}

ABSTRACT

Western mind always remains muddled to fathom the Islamic belief "Prophethood" but it is grand reality that the West has contributed a lot in "Sirah Writing" from 17th to the present age. Although, in primary literature, Western scholars have delineated their abhorrence in this regard, without any research analysis. They usually used to twist the facts andmisinterpret the text in attempt to sustain their assumption under their own perception. In the present age, literary change is seen in Western Writings that scholars have admired categorically the demonstrative Personality of Mohammad (PBUH) as well as they have praised his attributes as authoritative leader, Reformer, Peace maker etc. It will discuss the changes which were seen in Western writings about Sirah and analysis the causes andfacts accordingly. It will also throw light on the Western assumption about Prophet Muhammad (PBUH); which has been prevailed in their writings before 19th even changed now. Islam is religion of Peace and Prophet of Islam has sent as" Blessing for All the Universe" from God Almighty so the question is what are the motives to bring forward theses western suppositions in this regard and at what extent it will affect? It will be discussed through comparative analysis among the Sirah books by Western Scholars Maxim Rodinson, Karen Armstrong and Michael Cook.

DOI: https://doi.org/10.54064/negotiations.v1i3.29

$$
\begin{aligned}
& \text { تحارف }
\end{aligned}
$$

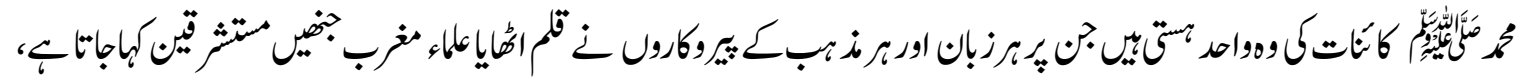

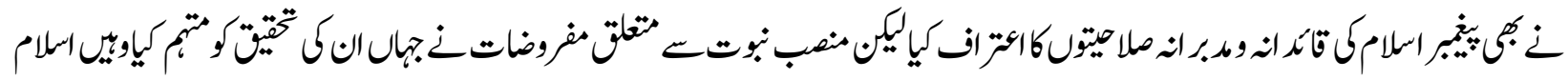




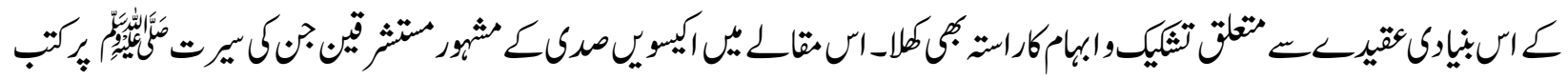

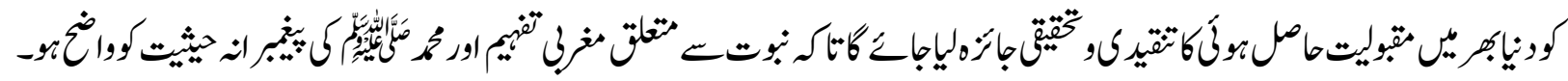

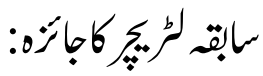

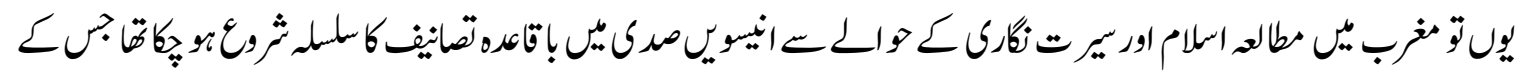

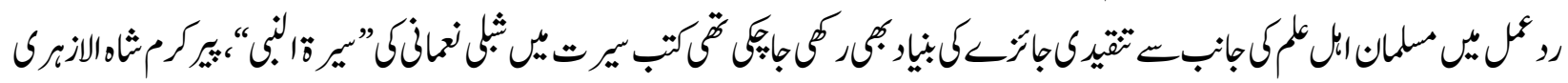

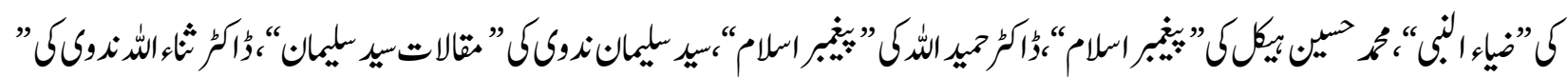

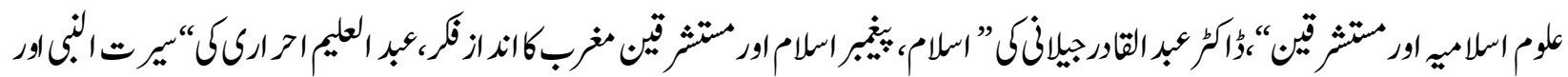

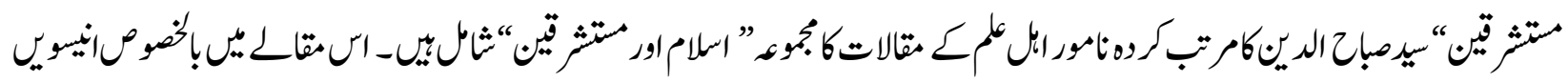

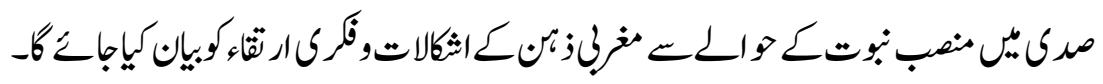

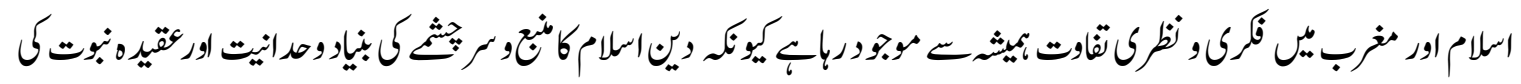

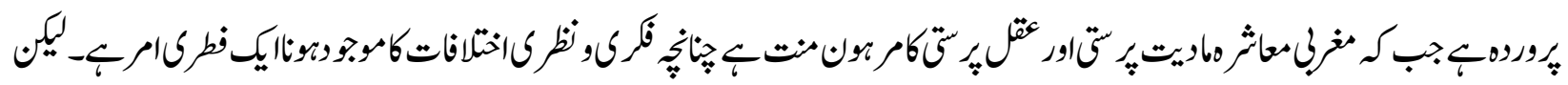

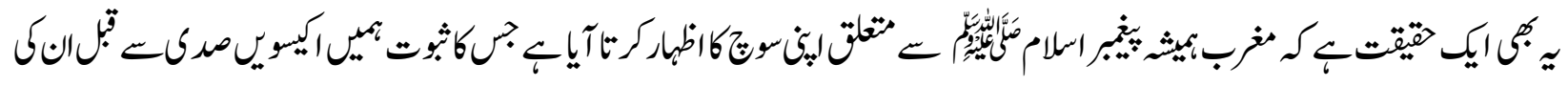

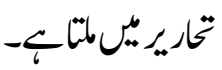

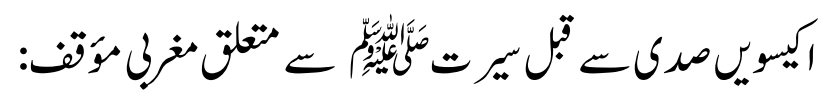

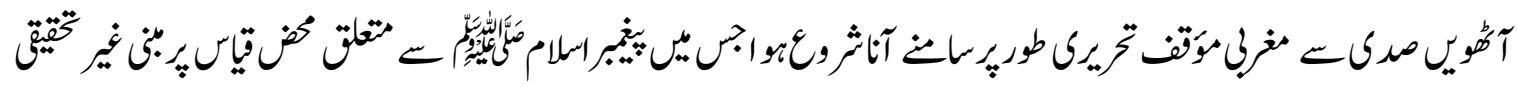

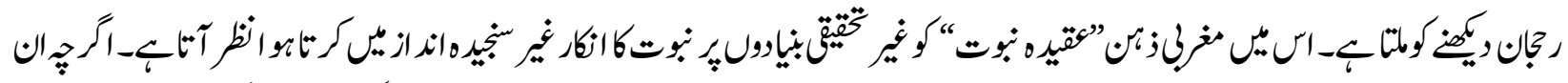

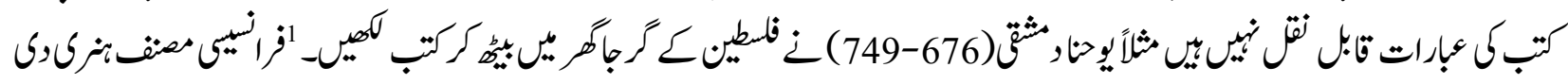

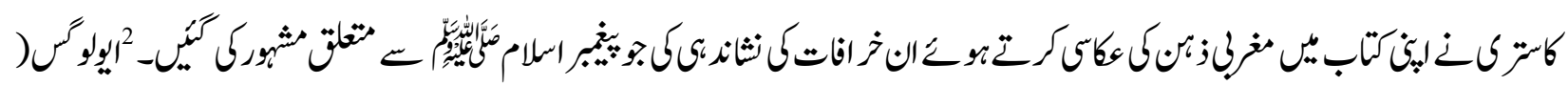
متوف3

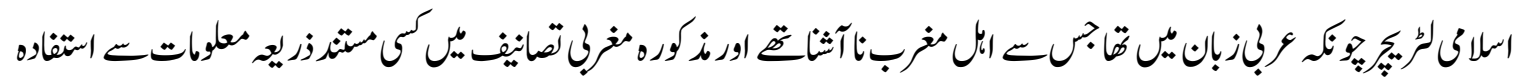

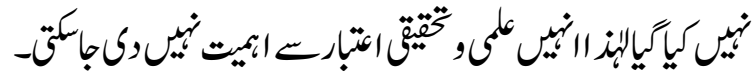

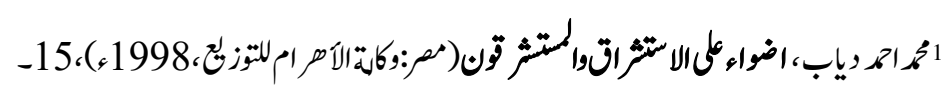
${ }^{2}$ Matthew Paris, Roger of Wendover's History (London: J. Haddon Printers, Castle street Finsbury), Vol-1, 74. ${ }^{3}$ Reinhart Pieter Anne Dozy, Spanish Islam (London: Chatto \& Windus Press, 1913),79. 


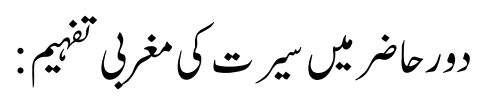

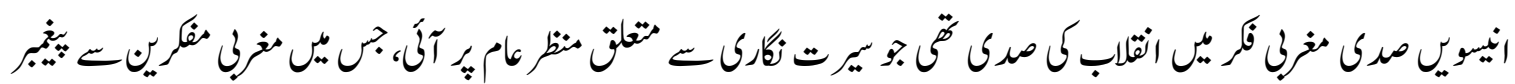

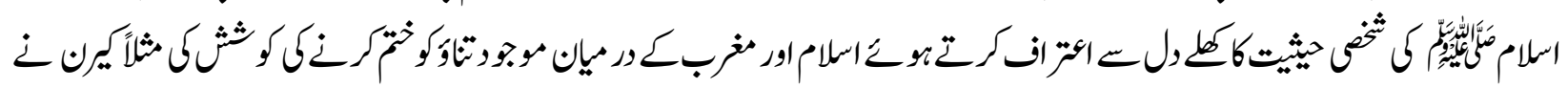

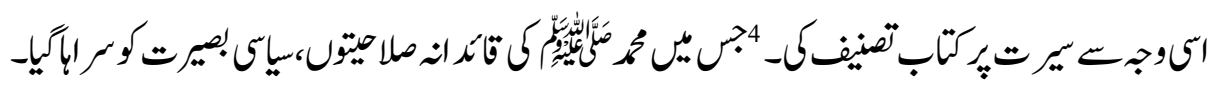

"As a skillful Arab politician, Muhammad knew how to use the rules of the tribal system to his own advantage" 5

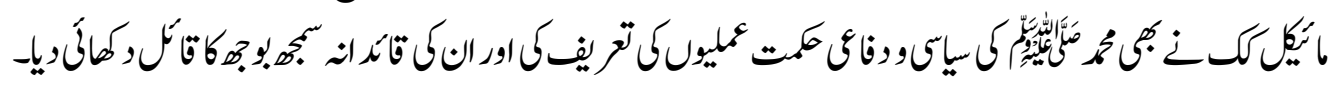

"Muhammad's years in Madina were also important in more narrowly religious terms, they saw a spread of his religion closely associated with his military success" $"$

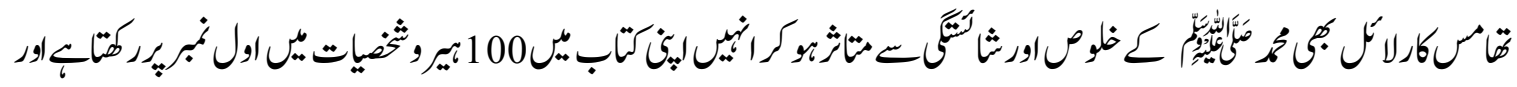

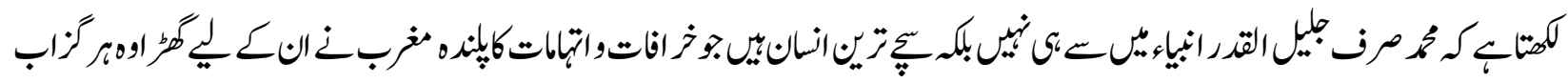

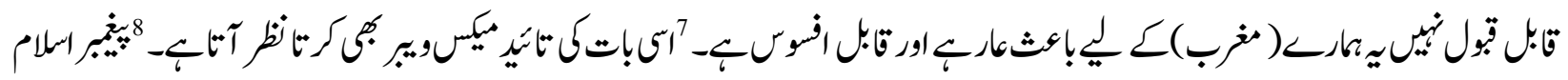

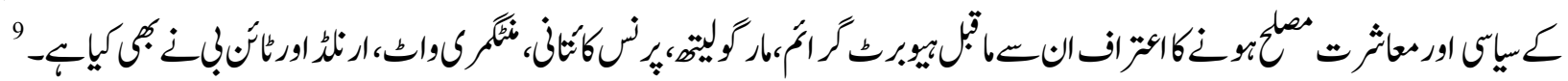

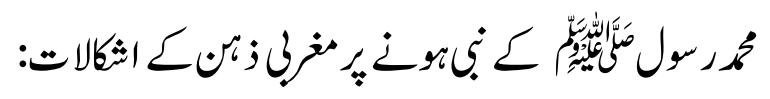

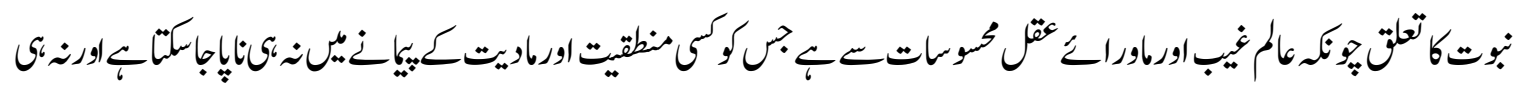

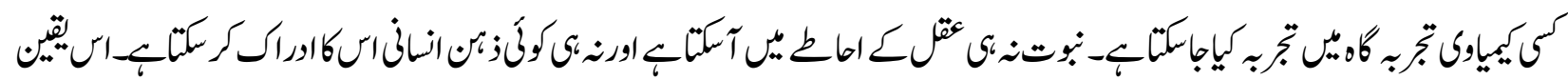

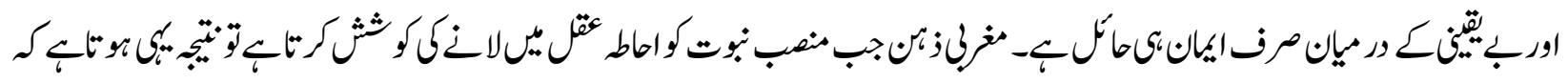

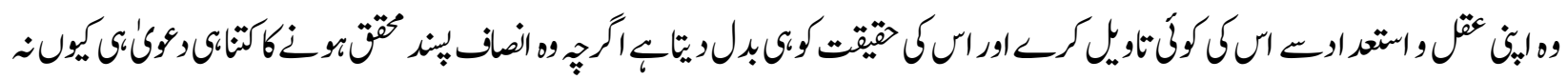

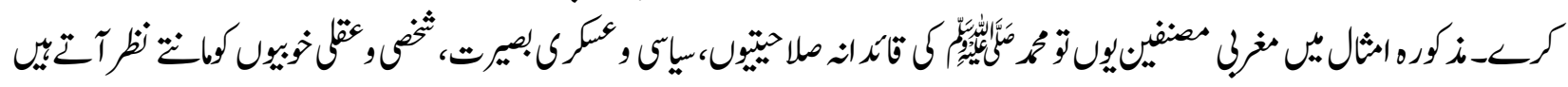

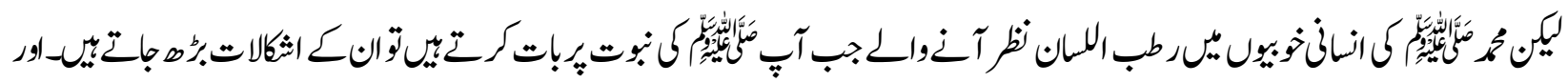

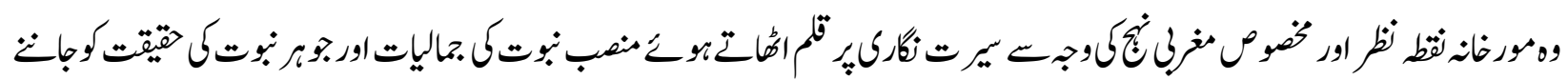

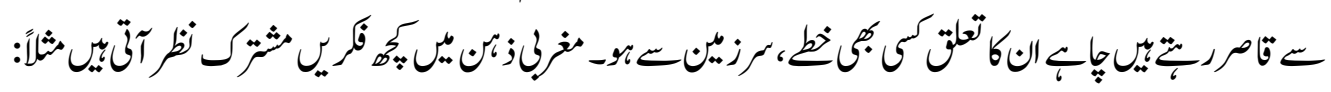

${ }^{4}$ Karen Armstrong, Muhammad: A Prophet for Our Time (New York: Harper Collins, 2006), 7.

${ }^{5}$ Karen Armstrong, Muhammad: A Biography of the Prophet (London: Phoenix Press, 2001), 277.

${ }^{6}$ Armstrong, Muhammad, 23.

${ }^{7}$ Thomas Carlyle, On Heroes, Hero-Worship, and The Heroic in History (Newyork: Longmans, Green and Co, 1906), 25.

${ }^{8}$ Max Weber, The Sociology of Religion (Massachusetts: Beacon Press, 1993), 47.

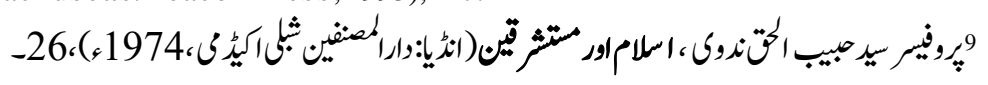




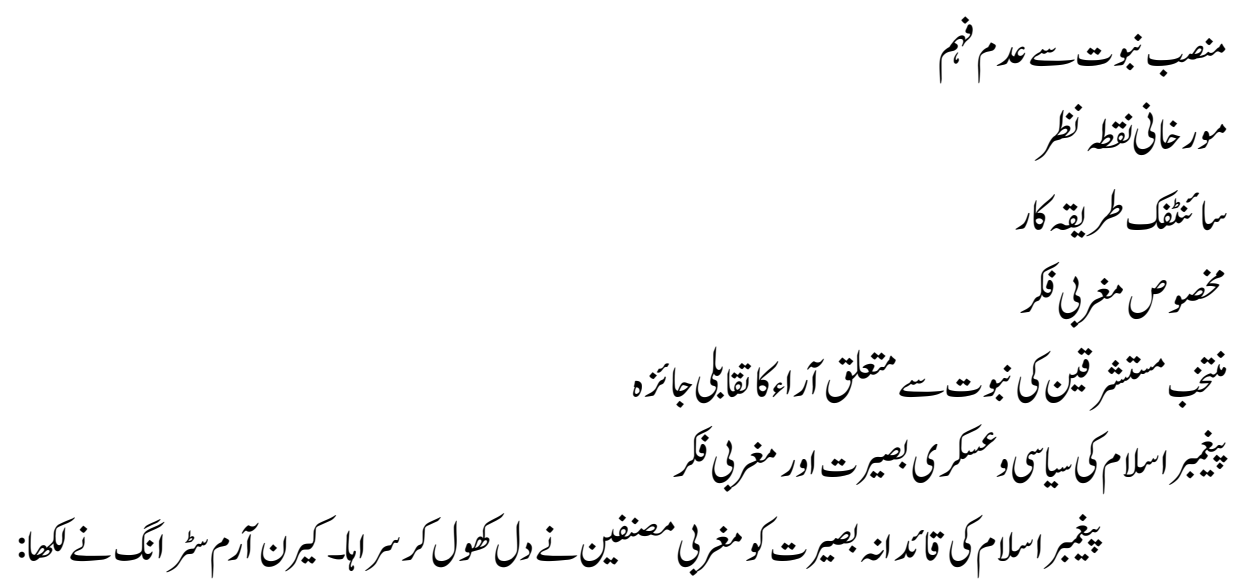

"Muhammad has been a familiar figure up to this point. Having endured years of persecution and defeat, he has been a Prophet unrecognized in his own country. But after the hijra Muhammad became spectacular success, politically as well as spiritually and the Christian west always distrusted this aspect of his career. ${ }^{10}$

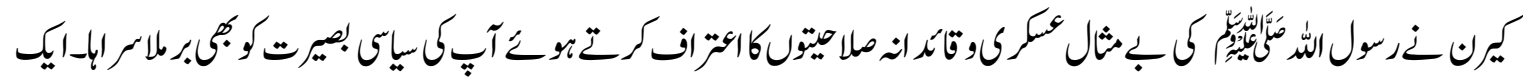

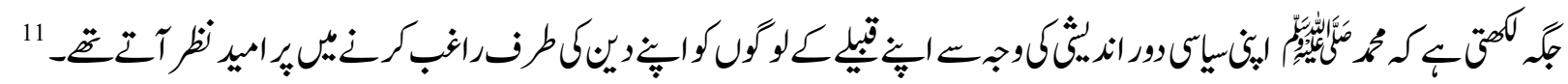

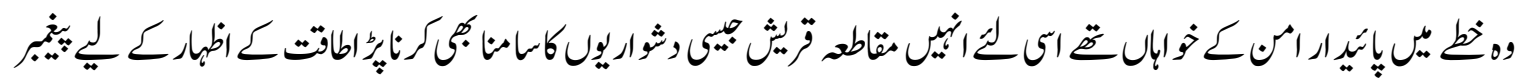

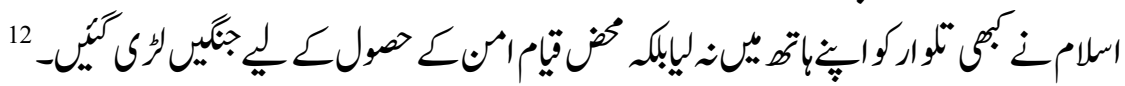

No radical, social and political change has ever been achieved without bloodshed and because Muhammad was living in the period of confusion and disintegration. Peace could be achieved only by the sword. ${ }^{13}$

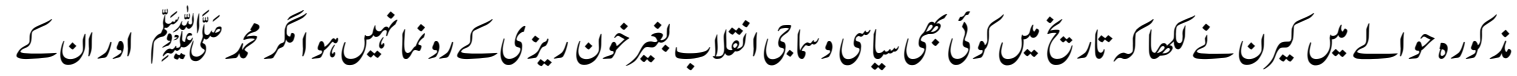

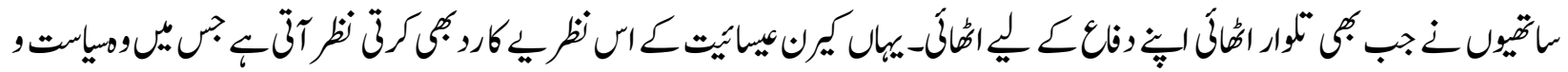

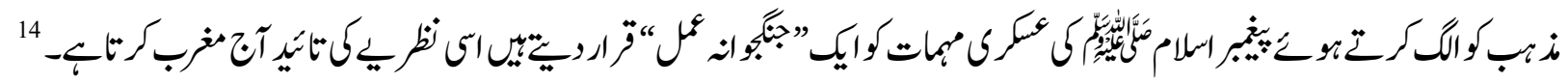

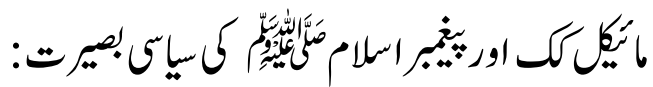

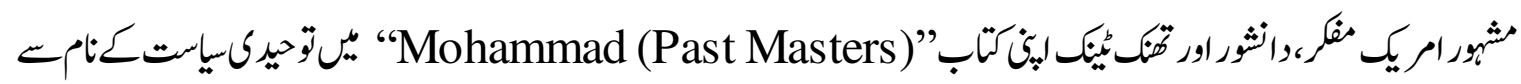

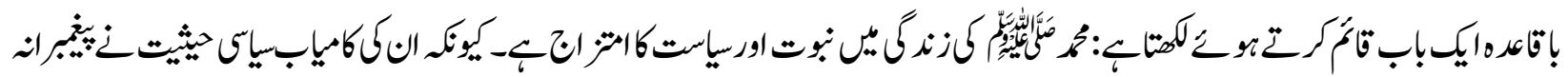
مقام كو تقيت بكثن.

\footnotetext{
${ }^{10}$ Karen Armstrong, Muhammad: A Biography of the Prophet (London: Phoenix Press, 2001), 164.

${ }^{11} \mathrm{Ibid}, 107$.

${ }^{12}$ Ibid, 165.

${ }^{13} \mathrm{Ibid}$.

${ }^{14}$ Karen Armstrong, Muhammad: A Prophet for Our Time (New York: Harper Collins, 2006), 125.
} 
The traditional biography of Mohammad presents his career as a remarkable combination of religion and politics and this combination can fairly be seen as a Prophet until he became a successful politician, but at the same time, his political opportunity turned on his credentials as a Prophet. ${ }^{15}$

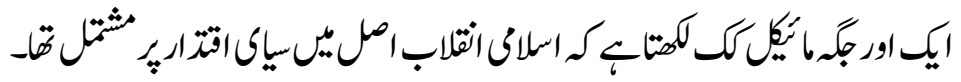

"Mohammad, as Arab merchant turned Prophet and politician who in 620 established a theocratic state. ${ }^{16}$

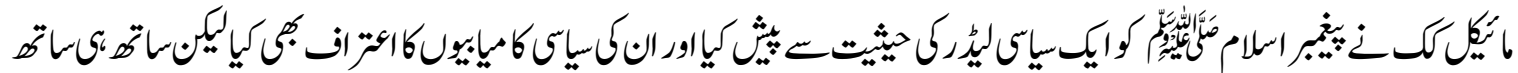

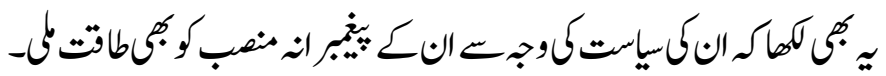

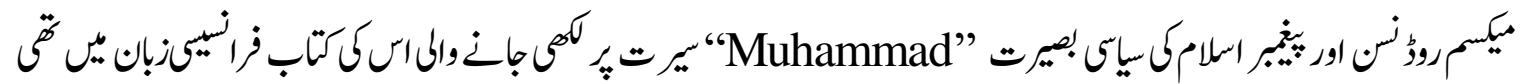

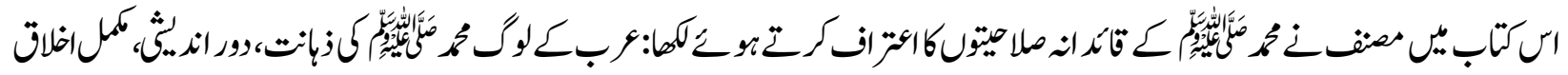

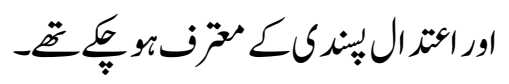

"People of Arab must have been struck by his intelligence, his calm, moral perfection, confidant and balanced manner. ${ }^{17}$

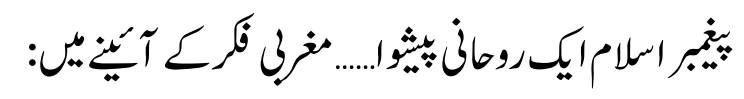

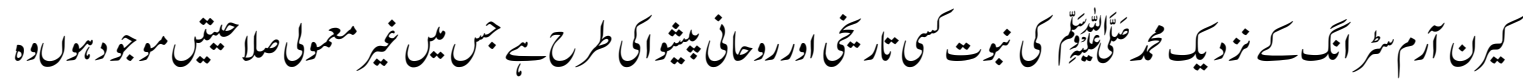

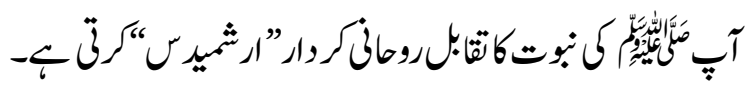

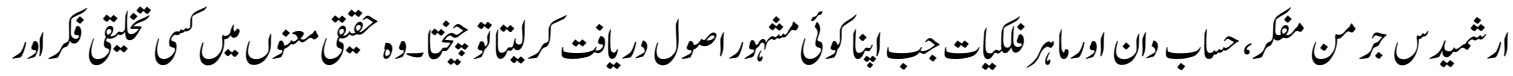

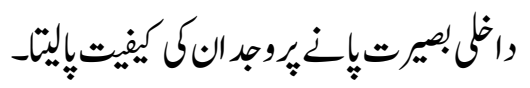

"Euraka" Archimedes, when he discovered his famous principle crying "Euraka" I have found it. He was in a receptive frame of mind and the solution seemed to have entered unbidden as it had an existence independent of his mind. ${ }^{18}$

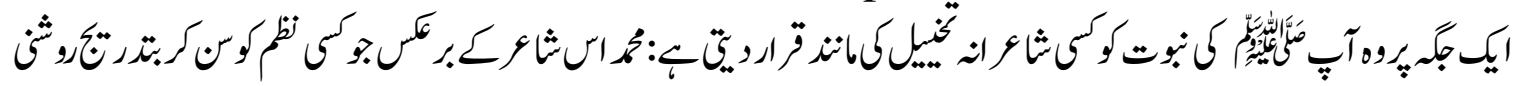

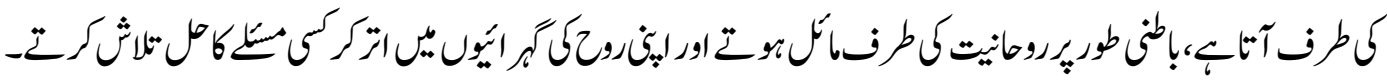

We shall see him turning inwards and searching his own soul for a solution to a problem, rather as a poet. Listen to the poem that he is gradually hauling to light. ${ }^{19}$

\footnotetext{
${ }^{15}$ Micheal Cook, Muhammad (United Kindom: Oxford University Press, 1983), 51.

${ }^{16} \mathrm{Ibid}, 2$.

${ }^{17}$ Maxim Rodinson, Muhammad. Translated by Anne Carter (USA: The Penguin Press, 1971), 49.

${ }^{18}$ Karen Armstrong, Muhammad: A Biography of the Prophet (London: Phoenix Press, 2001), 85.

${ }^{19}$ Ibid, 89.
} 


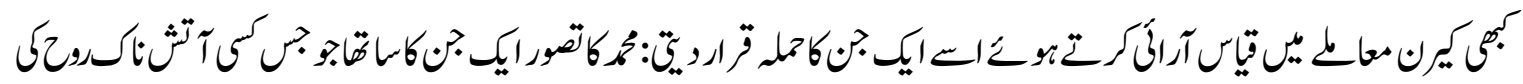

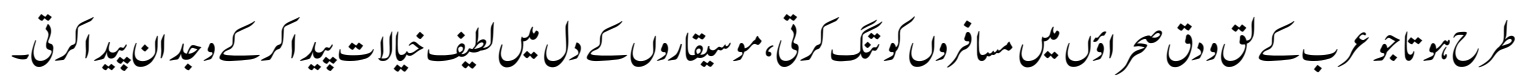

It seemed to him that a devastating presence had burnt into the cave, where he Was sleeping and gripped him in overpowering embrace, Mohammad was being attacked by Jinni, one of fiery spirit who haunted the Arabian steps, inspired the bards and soothsayers. ${ }^{20}$

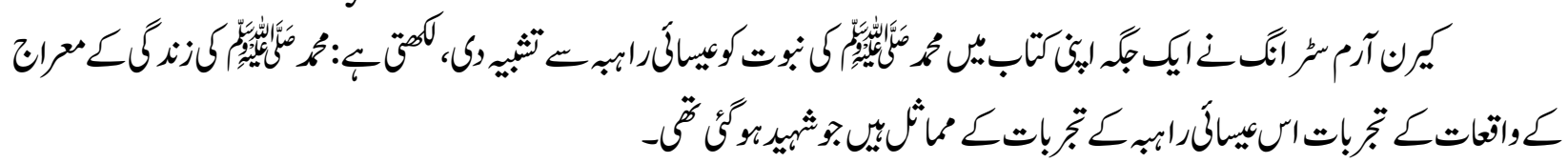

Some aspects of the Isra and the Miraj are very close to mystical imitations when people are making a painful passage from one mode of life to another, it is for example uncannily similar to the young matron Perpetua, Christian martyr. ${ }^{21}$

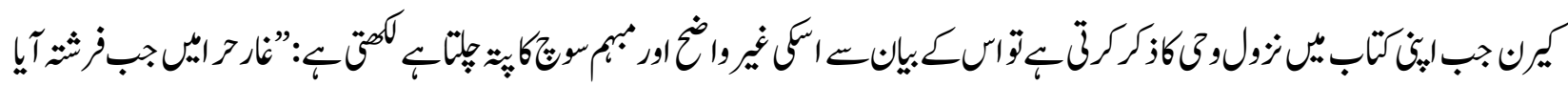

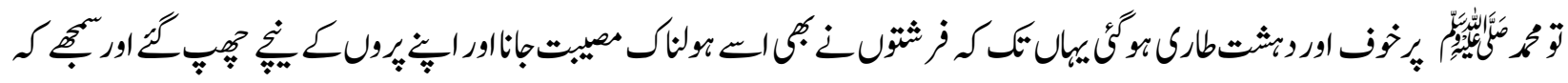

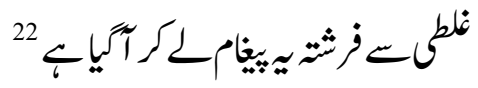

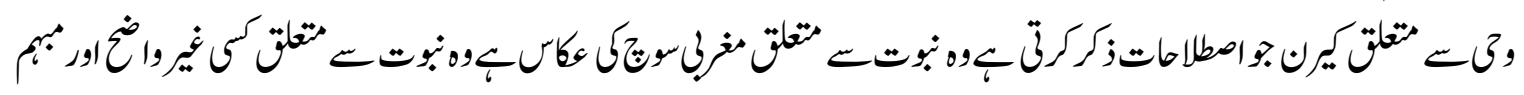

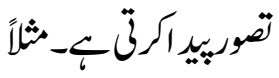

$$
\begin{aligned}
& \text { Malaise } 23 \\
& \text { Spiritual Retreat }{ }^{24} \text { روانظمثئن }
\end{aligned}
$$

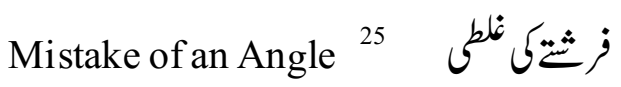

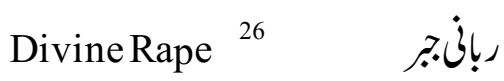

$$
\begin{aligned}
& \text { Inspiration }{ }^{27} \\
& \text { Searching Soul } 28 \text { روانثثابره }
\end{aligned}
$$

\footnotetext{
${ }^{20}$ Karen Armstrong, Muhammad: A Biography of the Prophet (London: Phoenix Press, 2001), 21.

${ }^{21} \mathrm{Ibid}, 141$.

${ }^{22}$ Ibid, 84.

${ }^{23}$ Karen Armstrong, Muhammad: A Prophet for Our Time (New York: Harper Collins, 2006), 74.

${ }^{24}$ Ibid, 82.

${ }^{25}$ Ibid, 83.

${ }^{26}$ Ibid, 84.

${ }^{27}$ Ibid.

${ }^{28}$ Ibid, 89.
} 


\section{ExplicitMessage 29}

DeeperUnderstanding 30 كمراوجران

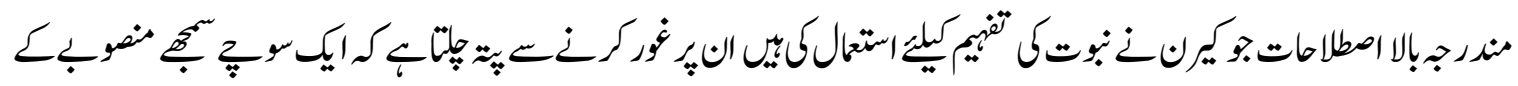

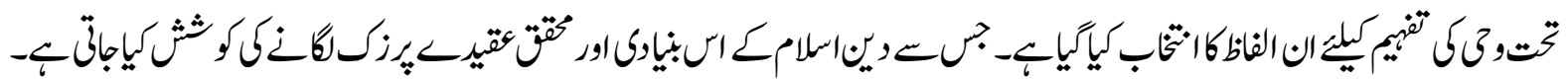

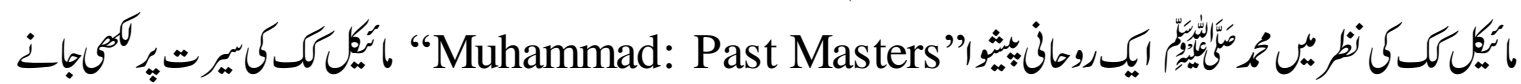

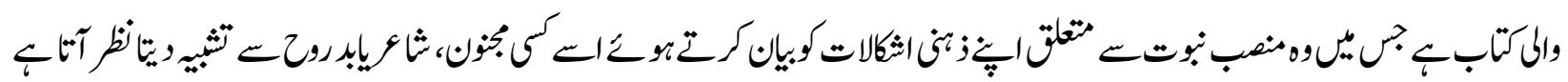

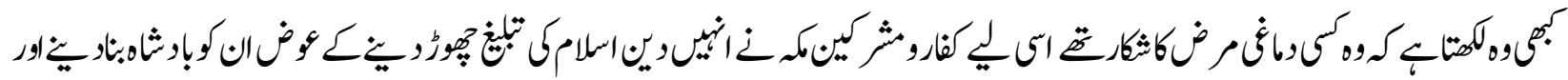

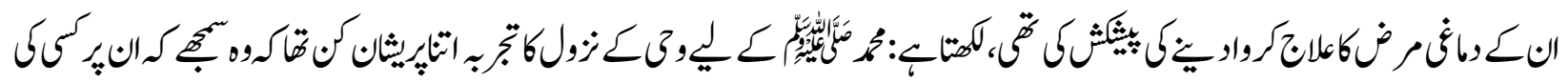

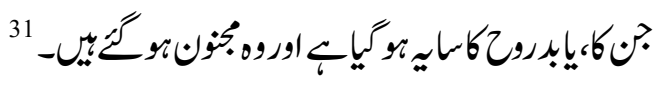

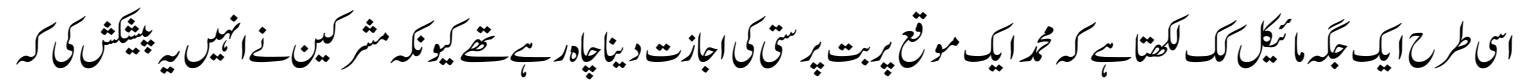

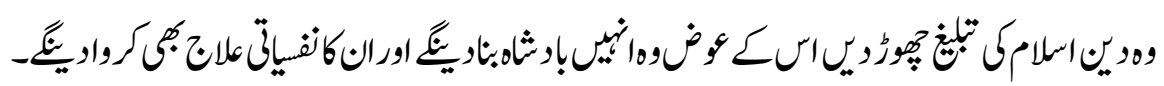

"There was no real trouble until Muhammad began to disparage the local pagan gods. This was considered offensive. Even then the pagan showed great willingnes $s$ to compromise. They offered to make Muhammad a king, or to obtain suitable medical treatment for his psychotic condition. Certainly on the one occasion when Muhammad yielded to the temptation to allow the pagan god a place in his religion"32

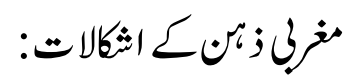

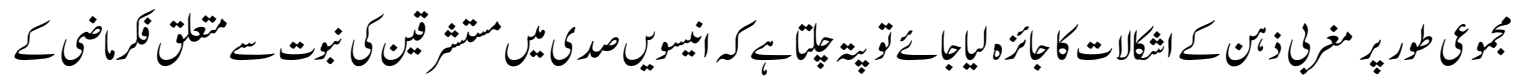

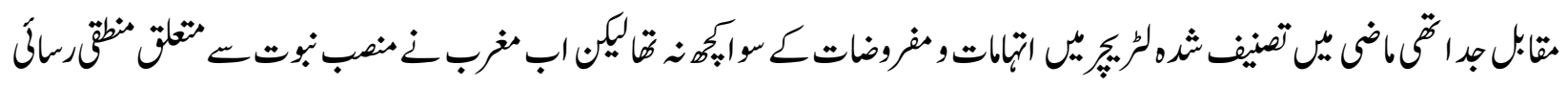

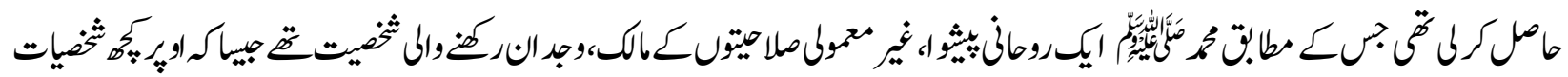

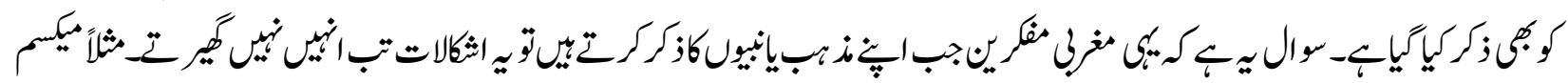

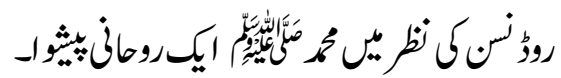

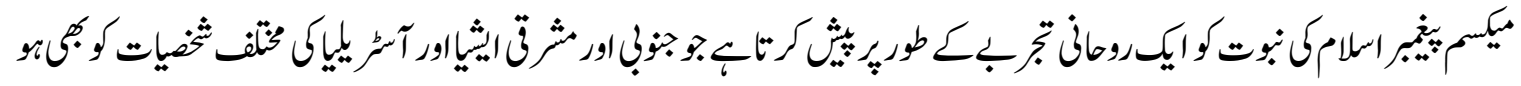

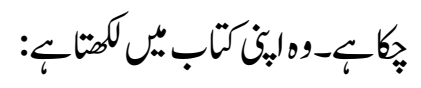

${ }^{29}$ Ibid.

${ }^{30} \mathrm{Ibid}, 225$.

${ }^{31}$ Micheal Cook, Muhammad (United Kindom: Oxford University Press, 1983), 15.

${ }^{32}$ Maxim Rodinson, Muhammad. Translated by Anne Carter (USA: The Penguin Press, 1971), 56. 


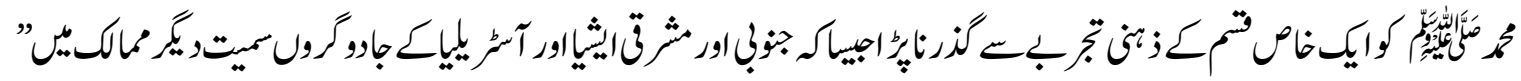

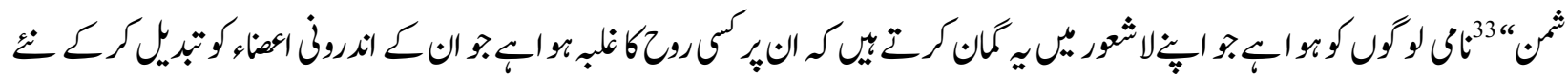

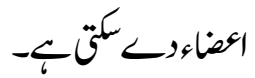

"Muhammad had some mental experience of the kind known to many "Shammans" of North and Central Asia and Australian magicians. At the moment of their imitation, they feel that a spirit has taken away their internal organs and replace them with new ones. ${ }^{34}$

$$
\text { نوبت كمغزباتثز تحاوراسك اثزات: }
$$

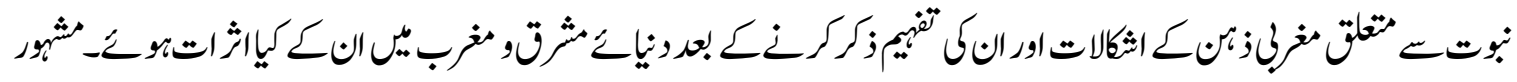

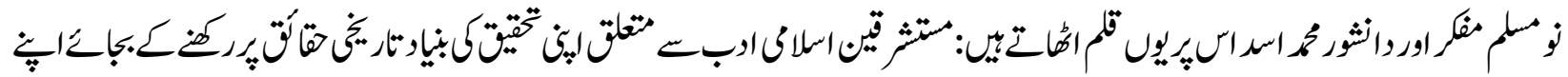

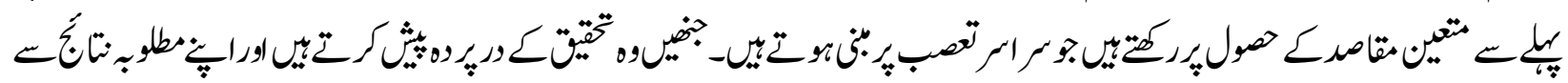

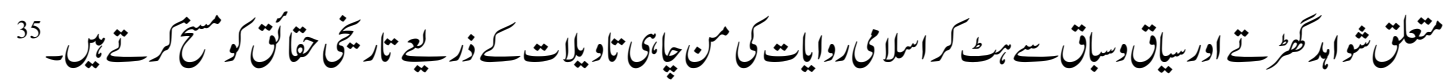

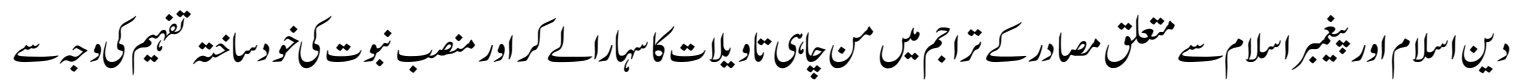

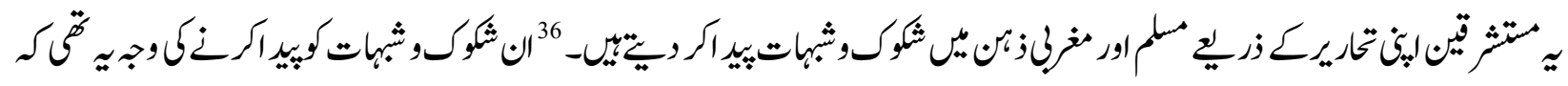

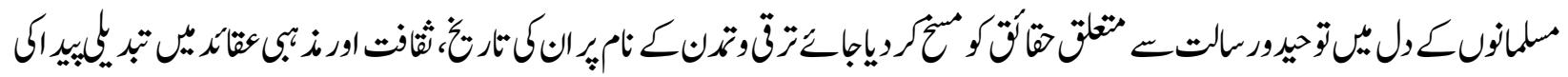

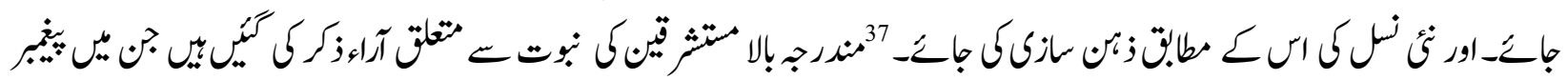

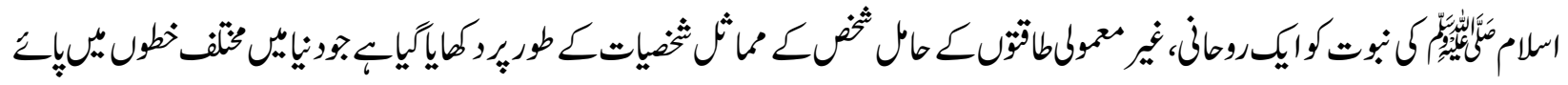
جإتبي

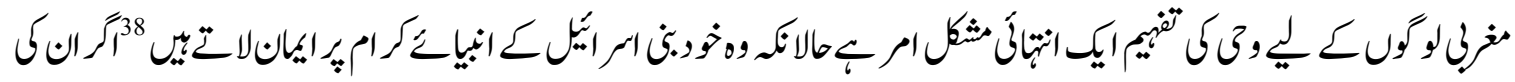

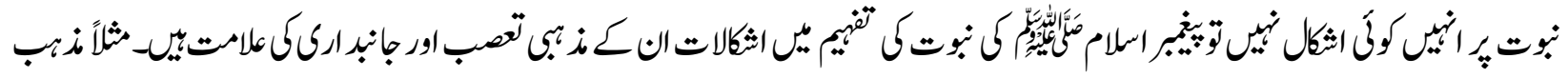

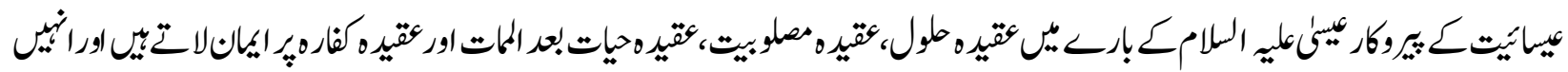

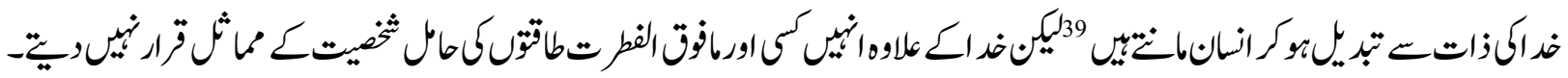

${ }^{33}$ Phil Hine, Walking Between the Worlds: Techniques of Modern Shamanism (New York: Pagan News Publications, 1986), 6.

${ }^{34}$ Micheal Cook, Muhammad (United Kindom: Oxford University Press, 1983), 34.

${ }^{35}$ Mohammad Asad, Islam at Cross Road (Gibraltar: Dar-Al Andalus, 1982), 49-50.

${ }^{36} \mathrm{Ibid}, 55-56$.

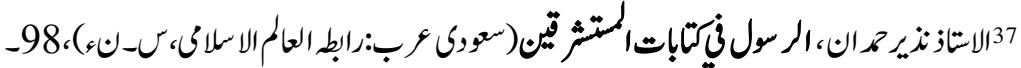

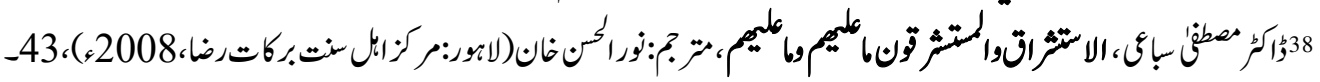

${ }^{39}$ H. Moutice Relton, Studies in Christian Doctrine (London: MacMillian Publishers, 1960), 28. 


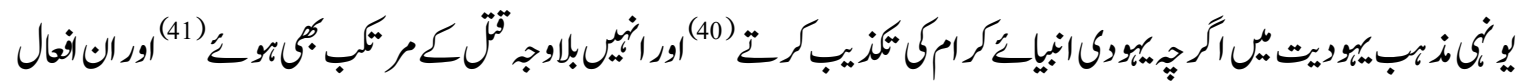

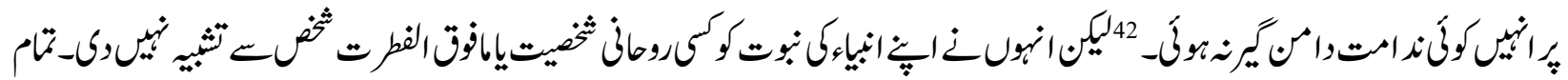

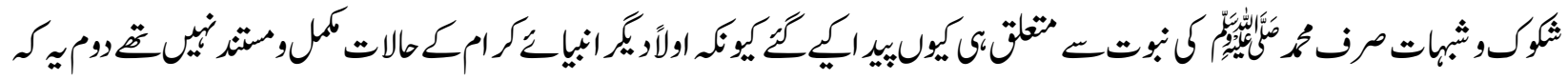

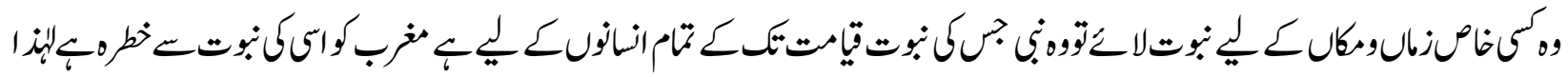

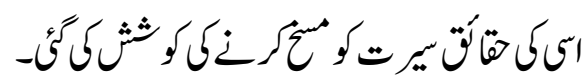

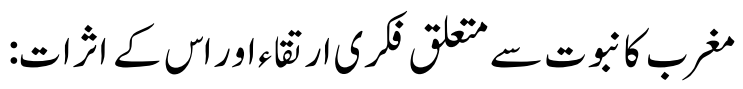

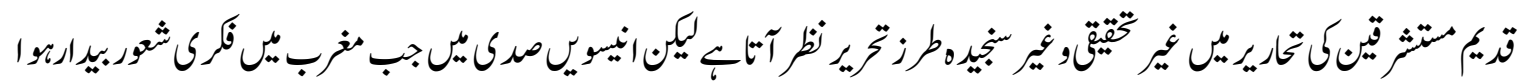

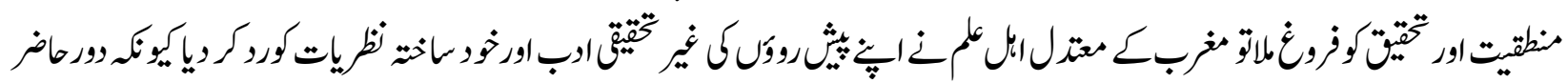

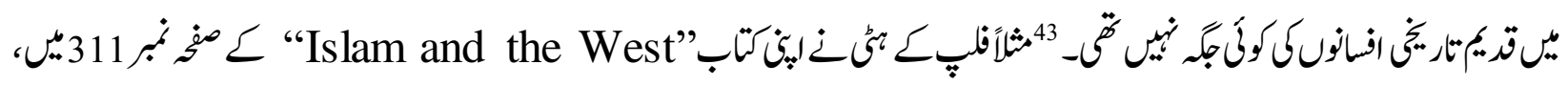

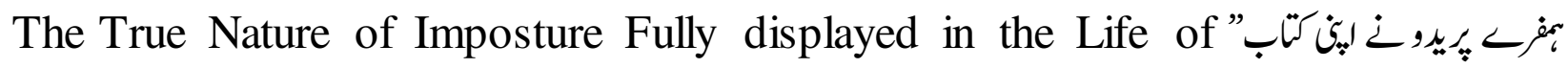
"Mohemet

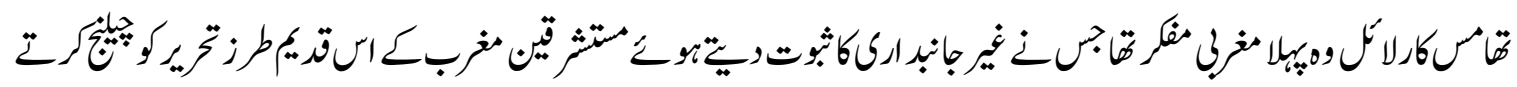

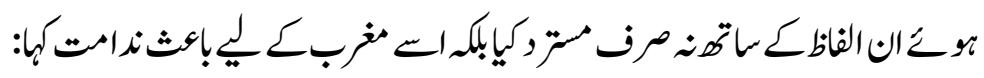
"The lies which well-meaning zeal has heaped round this man, are disgraceful to ourselves only"45

ناصم.كث:

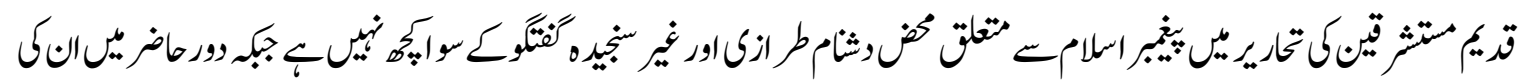

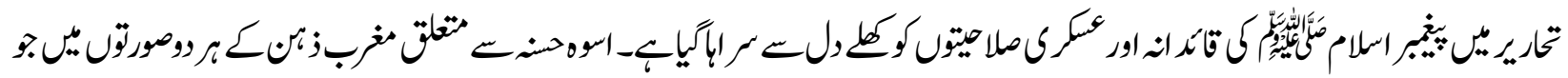

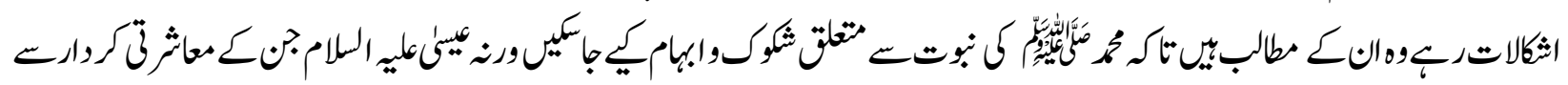

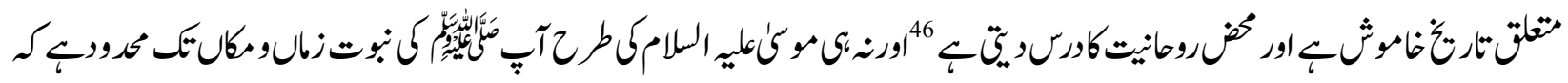

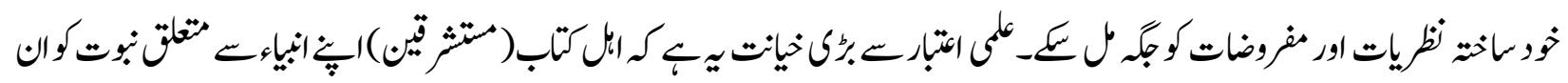

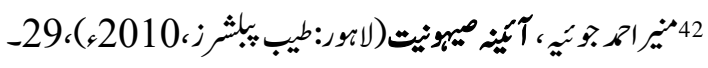

${ }^{43}$ Philip. K. Hitti, History of the Arabs (USA: MacMillian Publishers, 1970), 54.

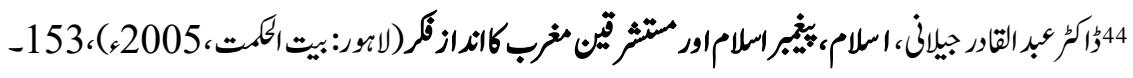

${ }^{45}$ Thomas Carlyle, On Heroes, Hero-Worship, and The Heroic in History (Newyork: Longmans, Green and Co, 1906), 311.

${ }^{46} \mathrm{Abd}$ Al-Jabbar Danner, The Islamic Tradition: An Introduction (Lahore: Institution of Islamic Culture, 2001), 53. 


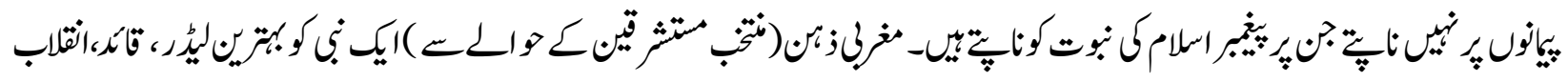

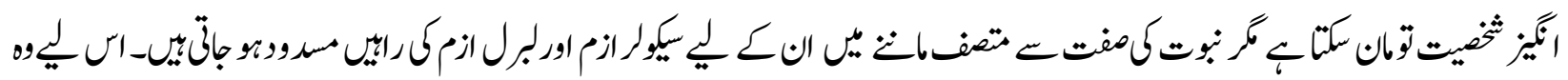

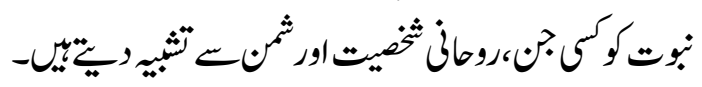

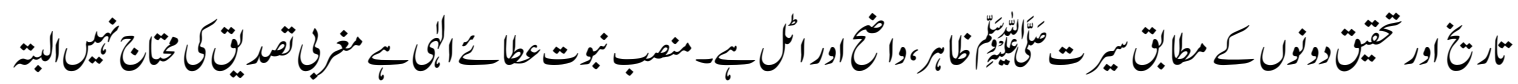

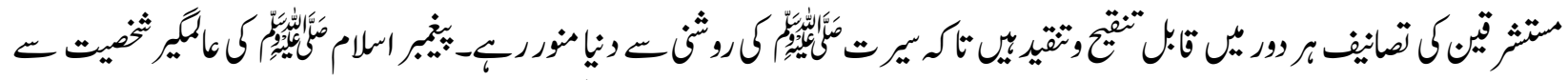

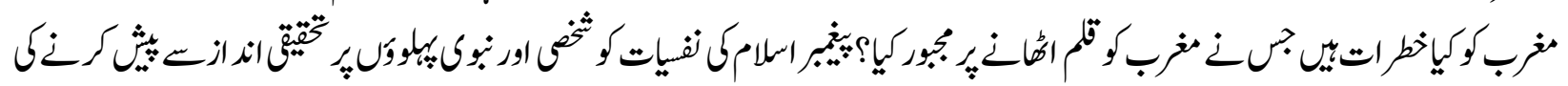

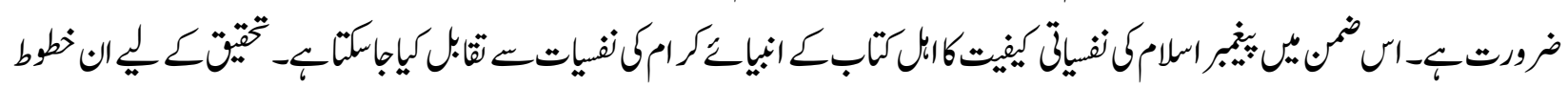

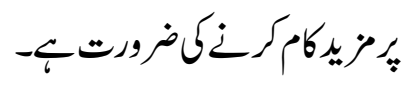

论动猔 